VOX PATRUM $22(2002)$ t. $42-43$

Michał MYŚLIŃSKI

(Warszawa, Instytut Sztuki PAN)

\title{
BIZANTYŃSKIE IKONY NADBRAMNE (Kult i funkcja)*
}

\section{PRZEKAZY ŹRÓDŁOWE I IKONOGRAFICZNE}

Wśród bizantyńskich ikon nadbramnych, otaczanych kultem już od początku istnienia Cesarstwa Bizantyńskiego, najpowszechniej znane były dwa wizerunki Chrystusa: ikona widniejąca nad Bramą Chalké w Konstantynopolu oraz acheiropoietyczny Mandylion - początkowo przechowywany w Edessie, a następnie przewieziony w roku 944 do stolicy Cesarstwa ${ }^{1}$.

Widniejąca nad Bramą Chalké ikona Chrystusa, którego ze względu na miejsce ekspozycji nazywano tes Chalkites, czyli „Ten-z-[bramy]-Chalké”2, była niezwykle mocno związana $z$ dziejami Bizancjum ${ }^{3}$. Losy tego wizerunku były dramatyczne, gdyż powszechnie był on traktowany jako jeden z symboli władcy i Cesarstwa, a tym samym byl obiektem cesarskiej polityki. Pierwsze wyobrażenie w Bramie Chalké powstało w czasach Konstantyna Wielkiego i przedstawialo „Zwycięstwo Krzyża”, : ukazano na nim postać Konstantyna Wielkiego z monogramatycznym krzyżem nad głową, depczącego węża - symbol szatana ${ }^{5}$. Przed 602 r. wizerunek Konstantyna został zastąpiony ikoną Chrystusa ${ }^{6}$, która

- Jest to skrót rozdziału obronionej w 1999 r. na Wydziale Historycznym UJ rozprawy doktorskiej pt. Przedstawienia bramne w sztuce antycznej i bizantyńskiej. Geneza - symbolika kult, napisanej pod kierunkiem prof. dra hab. A. Różyckiej-Bryzek.

${ }^{1}$ Por. Przegląd źródeł do dziejów tego wizerunku: A. Cameron, The History of the Image of Edessa: The Telling of a Story, „Harvard Ukrainian Studies” 7 (1983, ed. 1984) 80-94.

${ }^{2}$ Dzieje tego wizerunku wnikliwie przedstawil M. Chatzidakis, An Encaustic Icon of Christ at Sinai, „The Art Bulletin” 49 (1967) 197-208; por. także C. Mango, The Brazen House. A study of the vestibule of the Imperial Palace of Constantinople, Kobenhavn 1959, 135-142; W.I. Łazariew, Istoria wizantijskoj ziwopisi, Moskwa 1986, 141 i 161.

${ }^{3}$ Por. Mango, The Brazen House, passim.

${ }^{4}$ Por. Eusebius, Vita Constantini II 3, 15; R. Janin, Constantinople byzantin, Paris 1950, 111; A. Grabar, Iconoclasme byzantin, Paris 1984, 150-161.

5 Por. Mango, The Brazen House, s. 23.

6 Zamiany dokonano za panowania cesarza Maurycjusza, por. Grabar, Iconoclasme, s. 150; Mango, The Brazen House, s. 110 (tamże źródła referujące wizję Maurycjusza). 
7.ostała zniszczona w $726 \mathrm{r}$. z rozkazu cesarza Leona III w świadomym akcie ikonoklastycznym; czyn ten stał się zresztą symbolem obrazoburstwa ${ }^{7}$. Miejsce ikony zajął fundowany przez władcę krzyż z umieszczoną obok inskrypcją, wyjaśniającą powód obrazoburczego aktu ${ }^{8}$. Po ostatecznym wygaśnięciu herezji ikonoklastycznej w 843 r., nad Bramą Chalké obok krzyża ponownie umieszczono ikonę, która powszechnie czczona przetrwała z pewnością do 1348 roku'. Ikonografię Chrystusa Chalkitesa przekazują dość liczne zabytki, często opatrzone stosowną inskrypcją $\mathrm{C}^{10}, \mathrm{z}$ których najstarszym jest pieczęć Jana Pantechnesa $\mathrm{z}$ przełomu XI i XII wieku ${ }^{11}$. Na wszystkich tych przedstawieniach odziany w tunikę i kolobion Chrystus z nimbem krzyzowym wokól glowy, ukazany jest $\mathrm{z}$ prawą dłonią nieznacznie uniesioną $\mathrm{w}$ geście błogosławieństwa i księgą Ewangelii w lewej.

Ikoną specjalnego rodzaju był Mandylion - płat płótna grobowego, na którym w sposób cudowny odbiła się twarz Chrystusa ${ }^{12}$. Wedle pisanej ok. 325 r. Historii Kościoła Euzebiusza z Cezarei, wizerunek ten powstać miał na prośbę króla Abgara V wierzącego, że osobista obecność Chrystusa pomoże uleczyć toczący go trąd. Na dwór Abgara udał się jednak - już po śmierci Chrystusa apostoł Tadeusz (Addaj) z wizerunkiem Zbawiciela. Po przybyciu do Edessy Tadeusz nałożył wizerunek na swe czoło i wszedł do królewskiej komnaty, król zaś doznał w tym momencie wizji światłości ${ }^{13}$. Nieco późniejsze teksty nie rela-

${ }^{7}$ Por. Grabar, Iconoclasme, s. 151; rok ok. 730 podaje z kolei C. Mango (The Brazen House, s. 171-174). Akt zniszczenia ikony ukazano na miniaturze karty 66 r. rękopisu kroniki Jana Scylitzesa (Madryt, Biblioteka National, Scylitzes), zob. A. Cutler, Transfigurations. Studies in the Dynamics of the Byzantine Iconography, London 1975, 141-148, 155-156, 166-167; Lazariew, Istoria, s. 128 i 237; Grabar, Iconoclasme, s. 367, il. 142; wizję cesarza i zniszczenie ikony kwestionują A. Cameron i J. Herrin (Constantinople in the Early Eight Century. The Parastaseis Syntomoi Chronikai, Leiden 1984, 174-175).

${ }^{8}$ Por. Grabar, Iconoclasme, s. 152 i 161.

${ }^{9}$ Por. tamże, s. 152-153, 161; Mango, The Brazen House, s. 134.

${ }^{10}$ Inskrypcja często występuje w skrótach.

11 Por. Mango, The Brazen House, s. 137, il. 22.

12 Por. E. von Dobschütz, Christusbilder. Untersuchungen zur christliche Legende, Leipzig 1899; A. Grabar, Nierukotworiennyj Spas Panskowo Sobora, w: Seminarium Kondakowianum, Praga 1930, 5-34; S. Runciman, Some Remarks on the Image of Edessa, „The Cambridge Historical Journal" 3 (1931) 238-247; J. Kollwitz, Zur Frühegeschichte der Bilderverehrung, w: Das Gottesbild im Abendland, Bonn 1959, passim; Grabar, Iconoclasme, passim; T. Velmans, Valeurs semantiques du Mandylion selon son emplacement ou son associations avec d'autres images, w: Studien zur byzantinischen Kunstgeschichte. Festschrift für Horst Hallensleben, Amsterdam 1995, 173-184.

${ }^{13}$ Por. HE I 13. Tę wersję powtarza powstałe w X wieku Opowiadanie o wizerunku z Edessy dodając, że król porażony jasnością doznał uzdrowienia z trądu i paraliżu. Inną wersję o powstaniu Mandylionu przytacza tzw. Nauka Addaia z IV/V wieku, wedle której miał być on zwykłym obrazem namalowanym przez królewskiego posłańca Ananiasza, zob. Doctrina Addai, ed. G. Phillips: The Doctrine of Addai the Apostle, London 1876, thum. z syryjskiego W. Witakowski: Nauka Apostota Addaja, STV 22 (1984) z. 2, 181-213; M. Starowieyski, Apokryficzna korespondencja króla Abgara z Chrystusem, STV 15 (1977) z. 2, 177-200; Dobschütz, Christusbilder, s. 113 i 171. 
cjonują dalszych dziejów Mandylionu: po przewiezieniu do Edessy i okazaniu Abgarowi ślad po nim zaginął, co może thumaczyć fakt, iż po śmierci sprzyjającego chrześcijaństwu Abgara panowanie rozpoczęli władcy nieprzychylni nowej religii ${ }^{14}$. Dopiero oblężenie miasta przez wojska perskie w 544 r. przyczyniło się do ponownego pojawienia się Mandylionu, choć Prokopiusz, piszący o cudownym ocaleniu miasta nie przypisuje tego aktu żadnemu konkretnemu przedmiotowi. Podczas oblęzenia Mandylion nie był traktowany jako apotropaion, gdyż relikwią odeń ważniejszą był rzekomy list skierowany do Abgara V przez Chrystusa, który przyrzekał, że miasto nigdy nie zostanie zdobyte przez nieprzyjaciól; slowa listu wyryto na płycie, którą następnie umieszczono ponad bramą mias$\mathrm{ta}^{15}$. Ocalenie Edessy przypisuje Mandylionowi dopiero Ewagriusz Scholastyk piszący w 594 r., tzn. 50 lat po dramatycznych wydarzeniach ${ }^{16}$. Przytoczyl on opowieść o obmyciu Mandylionu wodą, którą następnie rozpylono na wieżę oblężniczą Persów, co doprowadziło do jej natychmiastowego pożaru. Od tego czasu relikwia przechowywana była w katedrze edesseńskiej w relikwiarzu złozonym na tronie, uroczyście noszonym w czasie procesji, o czym opowiada hymn liturgiczny - sugitha - O katedrze edesseńskiej ${ }^{17}$. Powszechnie już czczony Mandylion przewieziono w 944 r. do Konstantynopola i złożono w kościele Matki Boskiej w Blachernach; wydarzenia te zawarte są w napisanej na życzenie cesarza Konstantyna VII Porfirogenety, Opowieści o wizerunku z Edessy, odczytanej w kościele Hagia Sofia 15 sierpnia 945 roku. W Opowieści jednoznacznie stwierdzono, że sprowadzenie relikwii do stolicy Cesarstwa pozwoliło odzyskać tron prawowitemu władcy, sama zaś relikwia stała się apotropaionem Cesarstwa - przedmiotem chroniącym państwo ${ }^{18}$.

Przypisywanie obrazom cudownych interwencji należy wiązać z pojawieniem się na przełomie V i VI wieku szczególnego rodzaju wizerunków, tzn. obrazów acheiropoietycznych ${ }^{19}$. Interwencje te stają się w pełni zrozumiałe po uwzględ-

\footnotetext{
${ }^{14}$ Mandylionu już nie wspominają: Egeria przebywająca w Edessie w 383 r., sw. Efrem żyący w Edessie w końcu IV wieku, Jakub z Sarugu, zmarly w Edessie w 521 roku. Swiadczy to, ze zapewne juz w połowic IV wieku zaginęła pamięć o relikwii.

${ }^{15}$ Por. Procopius, Historia bellorum II 26, 1; E. Kitzinger, The Cult of images in the Age before Iconoclasm, „Dumbarton Oaks Papers” 8 (1954) s. 103, przyp. 68.

${ }^{16}$ Por. Historia ecclesiastica IV 27, PG 86, 2745-2749, thum. S. Kazikowski: Ewagriusz Scholastyk, Historia Koscioła, Warszawa 1990, 197-198; A. Grabar (Iconoclasme, s. 36-37) wiąże pojawienie się informacji o acheiropoietycznym wizerunku Chrystusa w Edessie z przewiezieniem do Konstantynopola ikony Chrystusa z Kamuliany, co nastąpiło w 574 roku, uzasadniając oba te fakty realnym zagrożeniem perskim.

17 Por. Sugitha de Cathedra Edessena, thum. z syryjskiego W. Kania, PSP 11, Warszawa 1973, 165-167; A. Grabar, Le témoignange d'une hymne syriaque sur l'architecture de la cathédrale d'Edesse au $V^{i e}$ siècle et sur l'architecture de l'édifice chrétien, „Cahiers Archeologiques” 2 (1947) 41-47; C. Mango, The Art of the Byzantine Empire 312-1435, New Jersey 1972, 57-58.

${ }^{18}$ Por. Narratio de imagine Edessena, PG 113, 425-454; Grabar, Nierukotworiennyj, s. 5-34, spec. 28-32.

${ }^{19}$ Por. Kitzinger, The Cult of images, s. 110-114.
} 
nieniu opinii przedstawionej przez Prokopiusza, iż „Chosroes, król Persów, powstał nie przeciw Justynianowi, lecz przeciw Bogu, którego czczą chrześcijanie" ${ }^{20}$. Wedle Prokopiusza uderzenie Persów na Edessę było wojną religijną, zatem ocalenic miasta interwencją sił Boskicl - wyrażoną działaniem relikwii nastąpiło w sytuacji zagrożenia religii, a nie tylko miasta i jego mieszkańców. Genezę apotropaicznej roli Mandylionu wyjaśnił Andre Grabar, wskazując na jej antyczne korzenie ${ }^{21}$. Zauważył on, że wizerunek Chrystusa odznacza się nienaturalnym ujęciem: uwidoczniono na nim bowiem twarz bez szyi, z kosmykami mocno wijących się włosów. Grabar stwierdzil, że ujęcie takie nie ma żadnej analogii w sztuce chrześcijańskiej, a przedstawieniem najbliższym formalnie oraz ideowo są znane w sztuce antycznej gorgonejony, tzn. idealizowane i nie budzące już gwałtownego lęku głowy Gorgony. Dodać tu należy, że głowa Gorgony stanowiła jeszcze w Cesarstwie Bizantyńskim powszechny talizman i swobodnie zestawiano ją z wizerunkami świętych bądź nawet Chrystusa ${ }^{22}$. Wizerunek na Mandylionie kontynuował zatem treść ikonograficzną gorgonejonów i budził podobne, a nawet identyczne, skojarzenia apotropaiczne (il. 1). Tezę tę potwierdza miejsce pierwotnego umieszczenia Mandylionu nad edesseńską bramą Kappe: powszechnie bowiem uważano bramę za najwłaściwsze miejsce dla różnego rodzaju sentencji, modlitw, a także obrazów o charakterze odstraszającym i ochronnym. Przyczyną takiego umieszczenia mogła być takżc chęć ekspozycji przedmiotu lub - przy nawrocie nieprzychylności dla chrzcścijan - konieczność jego ukrycia (zgodnie przyjmuje się, iz Mandylion ponownie odkryty zostal właśnie w płytkiej niszy nad bramą) ${ }^{23}$. Dodać trzeba, że przyczynienie się relikwii do ocalenia Edessy oraz jej przewiezienie do Konstantynopola w 944 r., spowodowały pojawienie się licznych przedstawień Mandylionu w malarstwie miniatorskim i ikonowym ${ }^{24}$. Wśród jego kilkunastu redakcji ikonograficznych ${ }^{25}$ za najbardziej zblizone do pierwowzoru uchodzą te, które powstały w czasie, gdy znajdowal się on jeszcze w stolicy ${ }^{26}$ (il. 2).

${ }^{20}$ Procopius, De bello persico II 12, Corpus Scriptorum Historiae Byzantinae, I, Bonnae 1894, 205, por. Grabar, Iconoclasme, s. 34.

${ }^{21}$ Por. Grabar, Nierukotworiennyj, s. 5-34, spec. 30-32.

22 Przykładem może tu być przechowywany w przemyskim Muzeum Narodowym talizman heliotropowy z wizerunkiem Chrystusa i Gorgony, powstały w Bizancjum w X wieku, por. J. Spier, Medieval Byzantine Magical Amulets and their Tradition, „Journal of the Warburg and Courtauld Institutes" 56 (1993) s. 59, nr 57, Pl. 5c.

${ }^{23}$ Opowiadanie o wizerunku z Edessy wiąże odkrycie relikwii bezpośrednio z perskim najazdem.

${ }^{24}$ Por. K. Weitzmann, The Mandylion and Constantine Porphyregennetos, w: Studies in Classical and Byzantine manuscript ilumination, Princeton 1971, 224-246.

${ }^{25}$ Ze względu na charakter ikonograficzny wyróżnia się dwa podstawowe typy Mandylionu: pierwszy przedstawia głowę $w$ nimbie na tle mocno rozpiętej i naciągniętej chusty, w drugim zaś widoczne są po obu bokach tkaniny jej skladki (tkanina układa się dodatkowo w leżący owal) - ten wariant jkonograficzny jest o wiele rzadszy, por. Grabar, Nierukotworiennyj, s. 5-34, spec. 16-17. 
Choć właśnie dwa wspomniane wyżej wizerunki Chrystusa wybijają się na plan pierwszy, to istnienie innych ikon nadbramnych w Bizancjum poświadczają zachowane teksty źródłowe - najczęściej żywoty świętych lub kroniki. Relacje o istnieniu ikon są nader skąpe i zazwyczaj ograniczają się do wzmianki o spowodowaniu przez obraz cudu, najczęściej uzdrowienia. Jedynie z pobocznego kontekstu relacji można wnioskować o zasadniczej ikonografii przedstawienia, choć bez możliwości dalszych ustaleń. Niezależnie od lapidarnej formy zawarte w przekazach źródłowych informacje przekonują dobitnie o istnieniu otaczanych kultem ikon nadbramnych już w 2. poł. V wieku. Wśród wizerunków wspominanych w źródłach wczesno- i średniobizantyńskich najłatwiej identyfikować grupę kilku zaledwie ikon; o pozostałych nie da się bezsprzecznie stwierdzić, iż nad bramami widniały na stałe. Grupę otwiera ikona $\mathrm{z}$ wizerunkiem św. Szymona Starszego, którą Teodoret opisał w 444 roku jako wiszącą ponad wejściem do warsztatu rzymskiego rzemieślnika i odnotował, iż zdaniem rzemieślnika wizerunek ten miał charakter apotropaiczny $^{27}$. Z kolei św. Jan z Damaszku wspominal w 1. poł. VIII wieku, iż pewien mieszkaniec Antiochii przypisywał identyczny charakter ikonie św. Szymona Młociszego, której zawieszenie nad drzwiami domu było wyrazem szczególnej pobożności oraz prośbą o dalszą opiekę świętego ${ }^{28}$. Cudowną rolę przypisywano także ikonie Chrystusa w aleksandryjskim Tetrapylonie, gdzie

${ }^{26}$ Por. Weitzmann, The Mandylion, s. 224-246, spec. 244-245, il. 230. Przywiezienie relikwii do stolicy i przekazanie jej w ręce cesarza Romana Lekapenosa zobrazowano we wspominanym już kodeksie Kroniki Jana Scylitzesa na miniaturze karty 131r. W scenie przekazania cesarz kłaniając się zbliża swą twarz do trzymanej w dłoniach relikwii, podpisanej odpowiednią inskrypcją: TO AГIOH MAH $\triangle$ Y $\Lambda$ I. Samodzieine wyobrażenia Mandylionu widnieją w kilku manuskryptach: zapewne najstarszym jest przedstawienie na miniaturze 12v. w XI-wiecznym kodeksie kazań Jana Klimaksa (Watykan, Biblioteca Apostolica, Rossianus 251). Dzięki umieszczeniu obok siebie dwóch identycznych wizerunków w symetrycznym układzie odniesć można wrażenie, iż na miniaturze przedstawiono jedną tkaninę i jej negatywowe odbicie. Przypuszczenie to zgodne jest $z$ legendą o cudownym powstaniu odbicia Mandylionu na scianie niszy, w której był on złożony. Ponieważ ścianę tę wzniesiono z cegły, powstałe na niej odbicie Mandylionu nazwano Keramionem; obu przedstawieniom towarzyszy inskrypcja: П $\Lambda$ AKEC ПNIKAI. Wyobrażenie Mandylionu znajduje się też na miniaturze 320v. powstałego na przełomie X i XI wieku Ewangeliarza Alaverdi (Tbilisi, Biblioteka Syjonu, $A$ 484). Identycznie ukazano relikwię również na karcie $286 \mathrm{z}$ XIwiecznego kodeksu Żywotów Metafrasta (Aleksandria, Biblioteka Greckiego Patriarchatu, Metafrastes). Mandylion widnieje także na ikonie z 945 roku, przechowywanej obecnie w klasztorze św. Katarzyny na Synaju (ikona podzielona jest na cztery pola - w prawym górnym polu widnieje wizerunek tronującego Abgara-Konstantyna trzymającego horyzontalnie rozwinięty Mandylion). Sceny z historii uzdrowienia króla Abgara widnieją również na miniaturze 192v. Menologionu z 1063 roku (Moskwa, Gosudarstwiennyj Istoriczeskij Muzej, gr. 9) oraz na miniaturze karty XIV. powstałego na przelomie XIV i XV wieku Zwoju (Nowy Jork, Morgan Library, cod. 299).

${ }^{27}$ Por. Theodoretus, Historia religiosa 26, PG 82, 1473A; Kitzinger, The Cult of images, s. 94, przyp. 32 i s. 111 , przyp. 102.

${ }_{28}$ Por. Oratio de imaginibus III, PG 94, 1393D; Kitzinger, The Cult of images, s. 97 i 109 , przyp. 98. 
znajdowala się ona jeszcze w 787 roku $^{29}$; co prawda moc uzdrawiającą posiadała oliwa z lampek plonących przed obrazem, jednak właściwości te nadawała oliwie właśnie ikona ${ }^{30}$. W żywocie św. Anastazjusza Persa wzmiankowana jest ikona $\mathrm{z}$ jego wizerunkiem, widniejąca nad tetrapylonem Cezarei już w 631 roku $^{31}$, natomiast w okolicy bramy Cherubinów w Antiochii - ikona Chrystusa ${ }^{32}$. Akcydentalne wyposażanie bram w święte wizerunki nastąpiło podczas oblężenia Konstantynopola przez Persów w 626 roku. Patriarcha nakazał wówczas, by w chwili największego zagrożenia wierni umieścili ikony Matki Boskiej z Dzieciątkiem na wszystkich bramach atakowanych umocnień, sam zaś rozpoczął procesję z obrazem Chrystusa ${ }^{33}$. Do rodzaju ikon nadbramnych wypada także zaliczyć kilkanaście przedstawień rzeźbiarskich, mozaikowych oraz freskowych widniejących do dziś w płytkich wnękach nad wejściami; spośród nich wymienić można wizerunek młodzieńczego Chrystusa z V wieku na kamiennych ościeżach portalu kościoła w Koja-Kalessi w Izaurii, a także wykonaną w końcu IX wieku mozaikę z proskynezą cesarza Leona VI przed tronującym Chrystusem w bazylice Hagia Sofia w Konstantynopolu ${ }^{34}$. Choć sama idea oraz historyczne przyczyny umieszczenia przedstawienia w narteksie kościoła są wciąż przedmiotem badań i interpretacji, to wyodrębnienie sceny stanowi podstawę uznania jej za wyobrażenie nadbramne ${ }^{35}$.

Do grupy przedstawień nadbramnych zaliczyć również należy liczne wyobrażenia symboliczne (najczęściej równoramienne krzyże lub monogramy) widniejące na nadprożach bądź węgarach bram i furt klasztorów syryjskich w Quasr-ibn-Wardan z ok. $480 \mathrm{r}^{36}$, Qualat-Kalota z $492 \mathrm{r}^{37}$, el-Anderin ${ }^{38}$, Baqirha $^{39}$ oraz Resafie ${ }^{40} \mathrm{z}$ pocz. VI wieku. Specyficzny rodzaj symboli nadbramnych stanowią zachowane inskrypcje, kute w nadprożach i węgarach bram domów lub wojskowych twierdz w Syrii ${ }^{41}$. Są to występujące zazwyczaj samo-

${ }^{29}$ Por. Kitzinger, The Cult of images, s. 106-107 i 111, przyp. 103.

30 Por. Sophronius, SS. Cyri et loannis miracula 36-39, PG 87, 3548-3574, spec. 3560; Kitzinger, The Cult of images, s. 106, przyp. 86.

31 Por. Kitzinger, The Cult of images, s. 108, przyp. 93 i s. 111, przyp. 104.

32 E. Kitzinger (The Cult of images, s. 111) zastanawia się dodatkowo na podstawie znanych źródel, przytoczonych w „Byzantinische Zeitschrift” 38 (1938) 362, czy ikona znajdowała się w masywie bramy, czy też wyłącznie w jej pobliżu.

${ }^{33}$ Por. Kitzinger, The Cult of images, s. 112.

34 Por. Grabar, Iconoclasme, s. 347, il. 119; Łazariew, Istoria, s. 72-73, il. 129 i 130.

${ }^{35}$ Mozaika ma charakter wotum fundatorsko-przebłagalnego, zapewne za akt czwartego z kolei małżeństwa cesarza, uznanego przez Patriarchę za rozpustę.

${ }^{36}$ Por. R. Krautheimer, Early Christian and Byzantine Architecture, London 1975, 261-263, il. 203 i 204.

37 Por. tamże, s. 160.

38 Por. tamże, s. $160,165,277,278$ oraz il. 225 ,.

39 Por. A. Grabar, Le premier art chrétien, Paris 1966, il. 42.

${ }^{40}$ Por. Krautheimer, Early Christian, s. 143, 241, 242, 274-277, il. 222-223.

${ }^{41}$ Por. F.W. Deichmann, Archeologia chrześcijańska, tłum. E. Jastrzębowska, Warszawa 
dzielnie, jedno- bądź kilkuwersowe fragmenty modlitw, inwokacje lub cytaty z Pisma św.; $z$ tych ostatnich część jest skierowana bezpośrednio do potencjalnego wroga jako ostrzeżenie przed gniewem boskim i silą obrońców twierdzy. Ich protektywny i apotropaiczny charakter rozpoznano już dość dokładnie zwracając uwage na powiązania $\mathrm{z}$ obrazami nadbramnymi. Wedle najnowszych ustaleń, inskrypcje widniejące nad wejściami wiodącymi w obręb domu, kościoła bądź twierdzy, stanowić miały swoistego rodzaju substytucję przedstawienia figuralnego będąc jednocześnie nośnikiem tych samych treś$\mathrm{ci}^{-42}$. Na domach prywatnych umieszczano najczęściej tekst: „Nasz Pan Jezus Chrystus, Syn Boga i Boskiego Logosu, mieszka tu, aby zło nie miało tu wstępu"43 lub: „Oto jest Brama Pana, przez nią wejdą sprawiedliwi”44. Liczniejsze odmiany inskrypcji występują na nadprożach kościołów, które opatrywano inskrypcjami: „Nasz Pan Jezus Chrystus, Syn Boga i Boskiego Logosu, mieszka tu, aby zło nie miało tu wstępu" "45, „Archaniele Gabrielu, pomóż

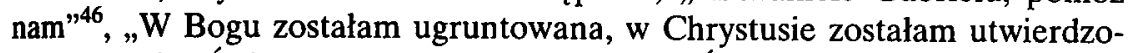
na, w Duchu Swiętym zostałam obwarowana. Święta Trójco, niepodzielna, błogosław nasze wejście i nasze wyjście, odtąd aż po wieki" ${ }^{47}$. Z kolei na nadprożach wejść do twierdz i warowni wojskowych umieszczano inskrypcje: „Pan Zastępów jest z nami, Bóg Jakuba jest dla nas obroną. Święty Boże, Święty Mocny, Święty Nieśmiertelny, za nas ukrzyżowany, zmiłuj się nad nami. Światło, Życie”48, „Oto jest Brama Pana, przez nią wejdą sprawiedliwi" (tekst rozdzielony jest przedstawieniem krzyża wpisanego w koło) ${ }^{49}$, „Chryste Jezu, stań się dla nas Bogiem obrońcą i domem schronienia oraz wieżą warowną w obliczu nieprzyjaciela. I zbuduj ten dom, gotując w nim chwałę dla Twego imienia na wieki przez modlitwy Bożej Rodzicielki Maryi i wszystkich Twoich świętych" (tekstowi towarzyszą wyobrażenia krzyży, golębi, owiec, liter A i $\Omega)^{50}$.

1994, 84-85; L. Małunowiczówna, Antologia modlitwy wczesnochrześcijańskiej, Lublin 1993, 402405. Inskrypcje nadbramne w kościołach Kampanii, odnoszące się do Chrystusa i Trójcy Świętej, wspomina Paulin z Noli, zob. Deichmann, Archeologia, s. 85. Należy również tu wspomnieć umieszczenie ponad wejsciem do kościola klasztoru św. Katarzyny na Synaju tekstu całego Psalmu 118: „Oto jest Brama Pana, przez nią wejdą sprawiedliwi”.

${ }_{42}$ Por. Deichmann, Archeologia, s. 84-85 i $94-95$ (tamże obszerna literatura problemu).

43 F.W. Deichmann (Archeologia, s. 84-85) podając informację, że napis ten byl dość rozpowszechniony, nie powołuje się jednak na konkretne przykłady.

${ }_{44}^{44}$ Por. Małunowiczówna, Antologia, s. 404, nr 346. Tekst jest 20-tym wersem Psalmu 118.

${ }_{45}^{45}$ Por. np. portal kościola w Herake; zob. Deichmann, Archeologia, s. 85.

${ }^{46}$ Por. Małunowiczówna, Antologia, s. 402, nr 340; inskrypcja pochodzi najprawdopodobniej $\mathrm{z}$ koscioła pod wezwaniem św. Archaniołów, wzniesionego w 527 roku. kosciola.

${ }^{47}$ Por. tamże, s. 404, nr 347; inskrypcją opatrzono wejście $w$ ogrodzeniu nieokreslonego

48 Tamże, s. 404, nr 342; inskrypcja powstała w 562/563 roku.

49 Tamze, s. 404, nr 346.

${ }^{50}$ Tamże, s. 405, nr 350; inskrypcję wyryto w 551 roku. 
Kończąc ten skrótowy przegląd zachowanych zabytków wspomnieć jeszcze wypada, iż większa liczebnie od ikon i przedstawień nadbramnych jest ich ikonografia. Wymienić tu można choćby powstałą w latach $432-440$ mozaikę łuku tęczow'ego w Santa Maria Maggiore w Rzymie ${ }^{51}$, na której w trójkątnym naczółku portyku kolumnowego ukazano tronującą Concordię ${ }^{52}$, a także wykonane ok. 526 r. mozaiki kościoła San Apollinare Nuovo w Rawennie, gdzie ukazano bramę wiodącą do miasta, w której pólkolistym luku wyobrażono Chrystusa depczącego węża ${ }^{53}$. Jedno $\mathrm{z}$ najwcześniejszych wyobrażeń nadbramnej ikony Chrystusa - zapewne nad Bramą Chalké, widnieje na datowanej na przełom VI i VII wieku plakietce $z$ kości słoniowej z Trewiru ${ }^{54}$ (il. 3). Ikony nadbramne przedstawiono też w wykonanym w 1066 roku Psalterzu Londyńskim (48 r., 115 v., 186 v. $)^{55}$, XI-wiecznym watykańskim psałterzu $(128 \text { r. })^{56}$, freskach pareklesionu konstantynopolitańskiego kościoła Chora (Kahriye amii) zrealizowanych na przełomie XIII i XIV wieku ${ }^{57}$ oraz freskach kościoła Michała Archanioła w Lesnowie, powstałych w latach $1347-1349^{58}$.

\section{KULT I FUNKCJA IKON NADBRAMNYCH}

Przekazy pisane dotyczące przedstawień nadbramnych, zawarte przede wszystkim w dziełach kronikarskich, stanowią grupę sześciu relacji. Kultu ikon nadbramnych dowodzi wspomniana już relacja Jana z Damaszku o zawieszeniu w końcu VI wieku wizerunku św. Szymona Młodszego ponad wejściem wiodącym do domu, co było wyrazem pobożności jego mieszkańca ${ }^{59}$. Autor ograniczając się wyłącznie do zrelacjonowania faktu zawieszenia obrazu, nie wspomniał jednak żadnych szczególnych czynności kultowych - proskynezy, modlitw bądź zawieszenia lampek (przejawem kultu był także zwyczaj zbierania oliwy $\mathrm{z}$ lampek przed ikoną Chrystusa w Aleksandrii). Z kolei w malarstwie miniatorskim czynności liturgiczne przed wyobrażeniami nadbramnymi zaliczyć trzeba do spectrum gestów „ogólnokultowych”, tzn. pokłonów, okadzania lub wy-

51 Por. Krautheimer, Early Christian, s. 93-94, 178, il. 45 i 46; Łazariew, Istoria, s. 24, 26, 31, 32, 35, 198, 201.

52 Por. Grabar, Le premier, il. 162.

53 Por. Krautheimer, Early Christian, s. 192-198; Łazariew, Istoria, s. 43, il. 50; O. von Simson, Sacred Fortress. Byzantine Art and Statecraft in Ravenna. Princeton 1987, s. 82, pl. 37.

${ }_{54}$ Por. Cutler, Transfigurations, s. 91, 166, 190.

55 Londyn, British Library, Add. 19. 352, por. Łazariew, Istoria, s. 88, 221, 222, 225.

56 Watykan, Biblioteca Apostolica, Vatican cod. gr. 752, por. Cutler, Transfigurations, s. 34 , 73, 100, 137, 143; Lazariew, Istoria, s. 222.

57 Por. Krautheimer, Early Christian, s. 448, 456, 469-471, 473, il. 400-401; Cutler, Transfigurations, s. 208; Łazariew, Istoria, s. 150, 161, 163, 165, 242, 249, 250.

58 Por. Cutler, Transfigurations, s. 131, 162, 234.

59 Por. Oratio de imaginibus III, PG 94, 1393D; Kitzinger, The Cult of images, s. 97 i 109 , przyp. 98. 
konywania gestu demonstracji $^{60}$ (il. 4). Nie ulega natomiast wątpliwości, że można zauważyć różnicę pomiędzy kultem ikon nadbramnych, a ich specyficzną funkcją w dziejacl Cesarstwa Bizantyńskiego; zróżnicowanie to dostrzegano już w Cesarstwie, zaś po jego upadku - w obrębie całej kultury ortodoksyjnej. Zwracając zatem baczną uwagę na rolę ikon nadbramnych, wyróżnić można tutaj ich trzy podstawowe funkcje: informacyjną oraz nierozerwalnie ze sobą związane apotropaiczną i protektywną, często wzajemnie się uzupełniające i stanowiące $\mathrm{w}$ całości przekaz ideowy wyobrażenia (ścisłe rozdzielanie tych dwóch ostatnich nie jest właściwe, gdyż właśnie ta komplementarność stanowi o pewnej odmienności ikon nadbramnych). Określenie tych trzech funkcji stało się możliwe na podstawie kilku przesłanek: ciągłości tradycji przedstawień nadbramnych w sztuce starożytnej i chrześcijańskiej, ikonografii wizerunku, a także bezspornych relacji źródłowych. Informacyjna rola przedstawień nadbramnych ma charakter powszechny - jej czytelność nie podlegała jakimkolwiek zmianom wynikającym z uwarunkowań kulturowych bądź historycznych. Tradycja obrazowa Kościoła Wschodniego pozwala stwierdzić, iż wizerunek pełnił rolę znaku treściowego i tak właśnie jeden z mieszkańców Antiochii potraktował ikonę $\mathrm{z}$ wizerunkiem św. Szymona Młodszego ${ }^{61}$; relacjonujący to Jan z Damaszku nie wspomniał, jakoby ikona cieszyła się specjalnymi względami właściciela $i$ innych chrześcijan - funkcja informacyjna czczonego obrazu była powszechnie zrozumiała, zatem nie było potrzeby jej podkreślania. Obrazy nadbramne określały przede wszystkim wyznanie ich właściciela - w czasie formowania się doktryny chrześcijańskiej obrazy Boga Wcielonego stanowiły wyraźny znak oderwania od tradycji żydowskiej, odrzucającej wszelkie antropomorficzne wyobrażenia Boga, zaś w okresie herezji ikonoklastycznej cześć oddawana ikonom nadbramnych była jawnym dowodem wierności ortodoksji. Można oczywiście tę rolę znaku „wyznania wiary” przypisać każdemu z czczonych wizerunków, jednak przekazy historyczne relacjonują niszczenie i powtórne umieszczenia ikon nadbramnych właśnic jako przejaw aprobaty bądź odrzucenia ikonoklaz$\mathrm{mu}^{62}$. Kolejną funkcją wyobrażeń nadbramnych był przekaz treści apotropaicznych i protektywnych. Jej ustalenie możliwe jest przede wszystkim w oparciu o teksty źródłowe, relacjonujące takie właśnie znaczenia obrazów, a w drugiej kolejności - interpretacji ich ikonografii. Ścisłe związanie obu funkcji nie pozwala jednoznacznie stwierdzić, która $\mathrm{z}$ nich ma charakter dominujący, a która jest jej uzupełnieniem, choć uwzględniając tradycje antyczne i przekazy literackie za nadrzędną uznać wypada funkcję apotropaiczną ${ }^{63}$. By funkcję tę w przed-

\footnotetext{
${ }^{60}$ Por. Ch. Walter, Sztuka i obrzqdek kościola bizantyńskiego, Warszawa 1992, passim.

${ }^{61}$ Por. Oratio de imaginibus III, PG 94, 1393D; Kitzinger, The Cult of images, s. 97 i 109, przyp. 98.

${ }^{62} \mathrm{Nie}$ jest tutaj rozwijane zagadnienie obrazowania wezwań kościoła, często przybierających również formę przedstawienia nadbramnego.

${ }^{63} \mathrm{Na}$ marginesie należy zastrzec, że powyższy podział nie ma charakteru stratyfikacyjnego,
} 
stawieniach odczytać, niezbędne jest wyjaśnienie terminu apotropaiczny, tak jak rozumieli go Bizantyńczycy ${ }^{64}$. Rdzeń słowa wywodzi się $z$ terminu greckiego tò

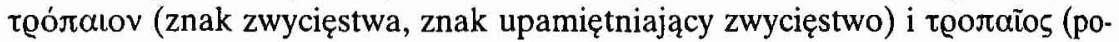
wodujący ucieczkę). Przede wszystkim należy jednak wywodzić go z określenia ảjot@ó $\alpha$ los (odwracający. działanie), oznaczającego tu „odwrócenie”, „odepchnięcie". Związanie sensu słowa $z$ dzialaniem militarnym pozwala jednoznacznie przyjąć, żc oznacza ono „odwrócenie, odepchnięcie działania militarnego". Uznać zatem trzeba, że apotropaicznym znakiem jest ten, dzięki któremu zostaje przelamane wrogie działanie wojenne, skierowane w określonym kierunku. Wlaśnie taki kontekst miała wspomniana przez Teodoreta ikona sw. Szymona Stupnika Starszego, zawieszona nad wejściem do warsztatu rzymskiego rzemieślnika ${ }^{65}$. Rolę tę wyznaczyl ikonie sam właściciel wizerunku, a podobną funkcję nadal ikonie św. Szymona Młodszego mieszkaniec Antiochii, o czym wiemy dzięki relacji Jana z Damaszku ${ }^{66}$. Oba przekazy źródłowe jednoznacznie pozwalają przyjąć, iż funkcja apotropaiczna była ikonom wyznaczona, nie stanowiła zaś naturalnego kontekstu przedstawienia, np. wynikającego $\mathrm{z}$ jego ikonografii, jak w przypadku wizerunków świętych wojowników. To zatem miejsce ekspozycji przedstawień implikowało ich funkcję apotropaiczną i protektywną, nawet jeśli była to ekspozycja wyłącznie czasowa; taką rolę nadano okazjonalnie ikonom Matki Boskiej iv czasie oblężenia Konstantynopola przez Persów w 626 roku, a następnie podczas kolejnego oblężenia w 717 r., gdy umieszczano ikony na bramach atakowanych przez nieprzyjaciela ${ }^{67}$. Uzupełnieniem funkcji apotropaicznej byla funkcja protektywna, czytelna wyłącznie w realnej przestrzeni budynku bramnego: odstraszające działanie wizerunku skierowane było na zewnątrz miejsca, w którym obraz był umieszczony, protektywne - ku przestrzeni wewnętrznej. Odstraszając najeźdźców obraz pełnil jednocześnie - jakby pasywnie - rolę ochronną wobec tych, którzy znajdowali się za obrazem, np. osłonięci ciągiem murów ${ }^{68}$. Przywołać tu zatem należy wezwanie Episkepsis, którym obdarzano Matkę Boską Blacherneńską. Termin ten oznacza właśnie miejsce schronienia, ochronę, a na komplementarność funkcji apotropaicznej i protektywnej jednoznacznie wskazuje określenie Mat-

lecz jest jedynie wskazaniem czytelnych, a zatem możliwych do wyodrębnienia, znaczeń zawartych w przedstawieniach nadbramnych.

${ }^{64}$ Por. A Patristic Greek Lexicon, ed. G.W.H. Lampe, Oxford 1978, 218: potrpaioj.

65 Por. Theodoretus, Historia religiosa 26, PG 82, 1473A; Kitzinger, The Cult of images, s. 94, przyp. 32 i s. 111 , przyp. 102.

${ }^{66}$ Por. Oratio de imaginibus III, PG 94, 1393D; Kitzinger, The Cult of images, s. 97 i 109, przyp. 98.

67 Por. Kitzinger, The Cult of images, s. 112.

68 Por. Ph. Grierson, Catalogue of the Byzantine Coins in the Dumbarton Oaks Collection and in the Whittemore collection, Dumbarton Oaks 1967-1973, s. 172, n. 508. O umocnieniach Konstantynopola zob. m.in. B.C.P. Tsangadas, The fortifications and Defence of Constantinople, New York 1980 (obszerna literatura wydanych źródeł i omówień). 
i Boskiej Blacherneńskiej epitetem apotropaicznym Ypermachos Strategos Walcząca Dowódczyni ${ }^{69}$ oraz protektyıvnym aprosmaketon oplon (Nieskruzona $\operatorname{Tarcza}^{70}$.

Stwierdzić zatem należy, że już u zarania sztuki przedstawieniowej i archiektonicznej istniały szczególnego rodzaju wyobrażenia, które określić można ako bramne oraz nadbramne. Ich cechą szczególną jest znaczenia symboliczne, idnoszące się do działania dwojakiego rodzaju: odstraszania oraz obrony. Obie e funkcje stanowią nierozerwalną całość, gdyż istnienie jednej implikuje obecıość drugiej. Wyrażają się one przede wszystkim formalnym wyglądem przedtawień bramnych, które w czasach starożytnych przerażały swą nienaturalnośiq̨ (hybrydy zwierzęce i ludzkie) lub znaczną siłą (agresywne zwierzęta, woownicy i władcy w pełnym uzbrojeniu, bóstwa $\mathrm{z}$ symbolami chwały). Zrozuniałe jest w kulturze chrześcijańskiej odrzucenie symboli i wyobrażeń starożytlych, jednak przyjęciu nowej ikonografii świętych wizerunków towarzyszyla iontynuacja ponadczasowej treści apotropaicznej, czego dowodem kojarzenie radycji ikonograficznej gorgonejonów $\mathrm{z}$ acheiropoietycznym wizerunkiem Zhrystusa. Zrozumiale jest także, że przedstawienia starożytne, później zaś юrtatywne ikony lub inne wyobrażenia chrześcijańskie widniejące w przetrzeni bram miast, osad i domów stanowily wyraźny znak wyznania i kultury eligijnej.

\section{BYZANTINISCHE TORIKONEN - KULT UND FUNKTION}

\section{(Zusammenfassung)}

Der Artikel behandelt Kult und Funktion byzantinischer Stadttorikonen und tützt sich auf Quellentexte und die ikonographische Überlieferung, wie zum Beipiel das Abbild des Christus Chalkites, das Mandylion, Darstellungen, die in Kontantinopel, Antiochia, Alexandria, und anderen Städten der Orthodoxie verehrt rurden. Das angeführte Quellenmaterial belegt eindeutig das Vorhandensein von lerartigen Ikonen schon für die Hälfte des 5. Jahrhunderts.

${ }^{69}$ Por. A. Papadopoulos, Les palais et les églises des Blachernes, Athenes 1928, 41.

${ }^{70}$ Por. M. Altaliates, Historia, Bonn 1853, 153, cyt. za: N.P. Kondakow, Ikonografia Bogotateri, Sankt Petersburg 1914-1915, 59-60), zob. także M. Myśliński, Kult i wizerunki Matki Boskiej , Blachernach oraz ich wptyw na sztukę ruskq, Kraków 1991, 11-20 (maszynopis pracy dyplomo'ej UJ). 
Die Analyse des Quellenmaterials erlaubt die Feststellung, dass die Verehrung von Stadttorikonen sich nicht vom Kult anderer Bilder unterschied: Man verehrte sie, indem man sich vor ihnen verneigte, sie in Prozessionen trug, sie beweihräucherte, Lampen anzündete etc. Ihre Besonderheit liegt hingegen in drei Funktionen, die nur für Stadttorikonen charakteristisch sind und ein deutliches Zeichen für das Weiterwirken der Traditionen der altertümlichen und antiken Kunst darstellen. Diese Funktionen ergänzen einander gegenseitig und bilden die Gesamtheit des ideographischen Programms: 1) Die Funktion der Information erfüllt die Ikone als deutliches Zeichen des Glaubens und der religiösen Kultur. 2.) Die apotropäische Funktion besteht darin, dass der Ikone wunderbare militärische Siege zugeschrieben werden. 3.) Die protektive Funktion wird dadurch sichtbar, dass der lkone ein ständiger Schutz sowie wunderbare Errettungen in Zeiten militärischer Bedrohung zugeschrieben werden. 


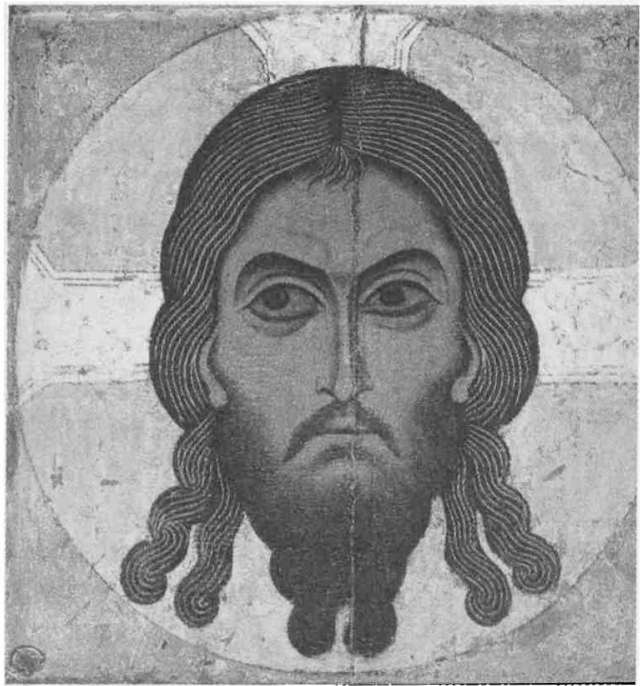

1. Chrystus Acheiropoietos; Nowogród (?), w. XII; za: D. Lichaczow, Novgorod Icons $12^{\text {th }}-17^{\text {th }}$ Century, Leningrad 1980.

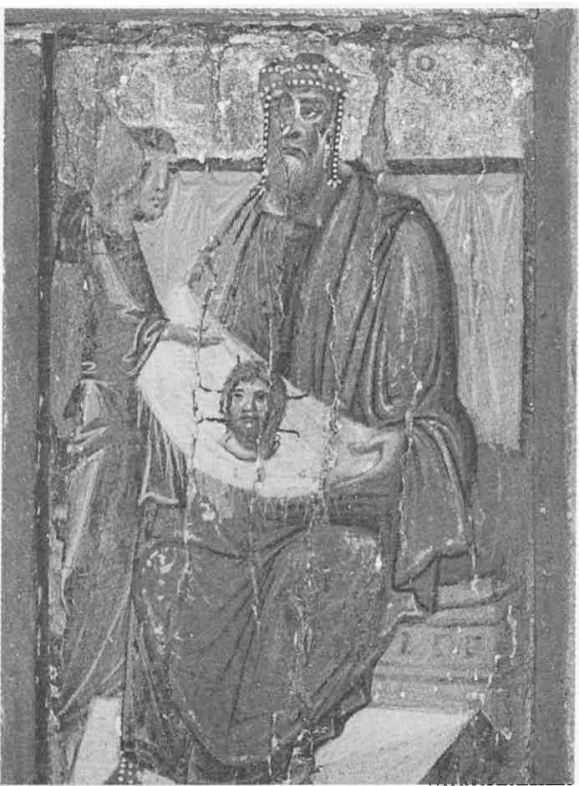

2. Cesarz Konstantyn VII Porfirogeneta jako król Abgar z Mandylionem; Synaj lub Konstantynopol, pol. w. X; za: K. Weitzmann, The Monastery od Saint Catherine at Mount Sinai, vol. I, Princeton 1976. 


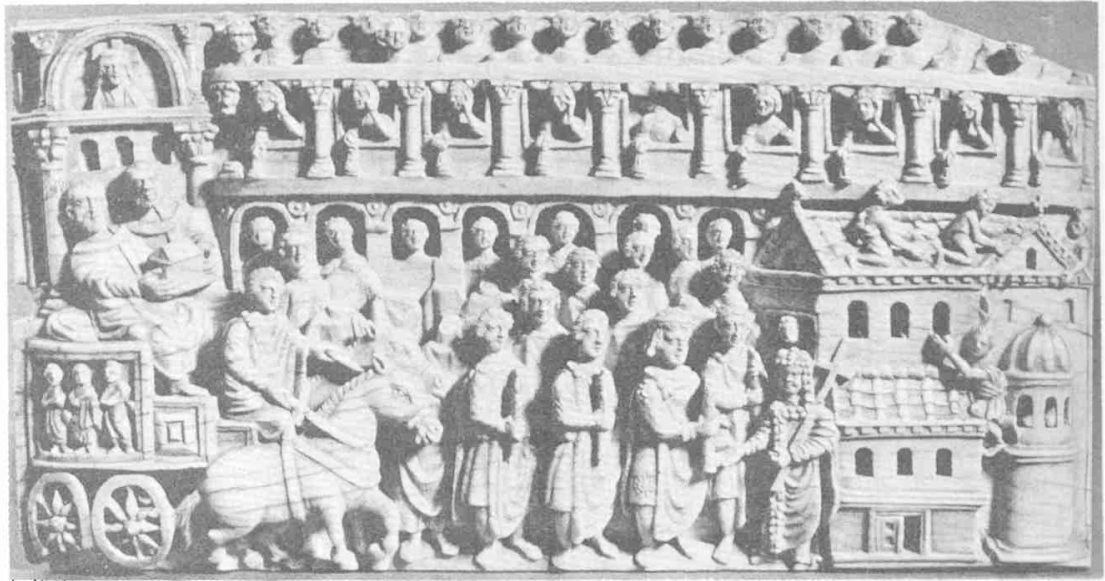

3. Wwiezienie relikwii św. Szczepana do Konstantynopola -

w tle brama Chalké z wizerunkiem Chrystusa Chalkitesa; Konstantynopol, pol. w. VI; za: J. Beckwith, Early Christian and Byzantine Art, London 1970.

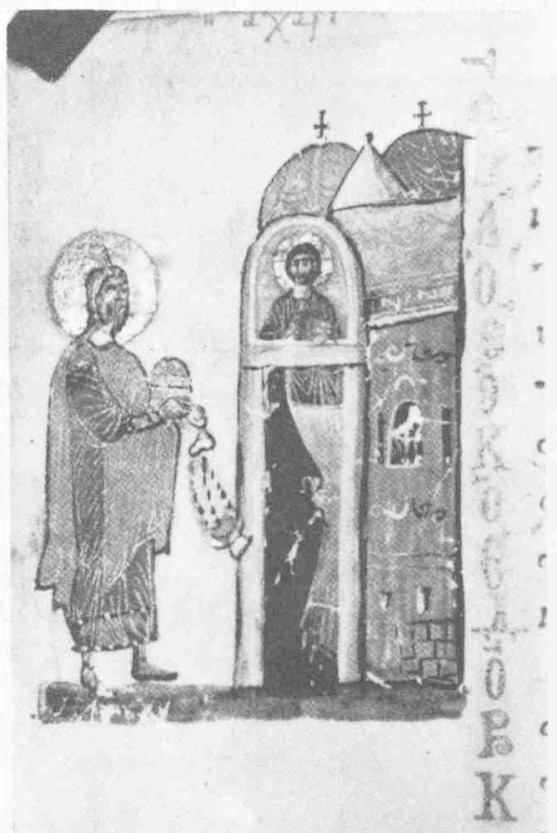

4. Okadzanie wejścia do świątyni z wizerunkiem nadbramnym;

Psałterz London Add. 19.352, fol. 186 v.; Konstantynopol, 1066;

za: S. der Nerssesian, Illustration des Psautiers Grecs du Moyen Age, II, Paris 1970. 